IZA DP No. 6199

Aggregate Impacts of a Gift of Time

Jungmin Lee

Daiji Kawaguchi

Daniel S. Hamermesh

December 2011 


\title{
Aggregate Impacts of a Gift of Time
}

\author{
Jungmin Lee \\ Sogang University \\ and IZA \\ Daiji Kawaguchi \\ Hitotsubashi University \\ and IZA \\ Daniel S. Hamermesh \\ University of Texas at Austin, \\ NBER and IZA \\ Discussion Paper No. 6199 \\ December 2011 \\ IZA
P.O. Box 7240
53072 Bonn
Germany \\ Phone: +49-228-3894-0 \\ Fax: +49-228-3894-180 \\ E-mail: iza@iza.org
}

\begin{abstract}
Any opinions expressed here are those of the author(s) and not those of IZA. Research published in this series may include views on policy, but the institute itself takes no institutional policy positions.

The Institute for the Study of Labor (IZA) in Bonn is a local and virtual international research center and a place of communication between science, politics and business. IZA is an independent nonprofit organization supported by Deutsche Post Foundation. The center is associated with the University of Bonn and offers a stimulating research environment through its international network, workshops and conferences, data service, project support, research visits and doctoral program. IZA engages in (i) original and internationally competitive research in all fields of labor economics, (ii) development of policy concepts, and (iii) dissemination of research results and concepts to the interested public.
\end{abstract}

IZA Discussion Papers often represent preliminary work and are circulated to encourage discussion. Citation of such a paper should account for its provisional character. A revised version may be available directly from the author. 


\section{ABSTRACT}

\section{Aggregate Impacts of a Gift of Time*}

How would people spend additional time if confronted by permanent declines in market work? We examine the impacts of cuts in legislated standard hours that raised employers' overtime costs in Japan around 1990 and Korea in the early 2000s. Using time-diaries from before and after these shocks, we show that these shocks were effective - per-capita hours of market work declined discretely. The economy-wide drops in market work were reallocated solely to leisure and personal maintenance. In the absence of changing household technology a permanent time gift leads to no increase in time spent in household production by the average individual.

\section{NON-TECHNICAL SUMMARY}

What would people do with their time if they didn't need to work for pay for so many hours? During a macroeconomic downturn, this seems like a silly question to ask; but over the past century time spent in market work has decreased. The difficulty in answering this question is that permanent cuts in work time have not been sudden, and could be attributable to slow changes in the ease of doing different things outside the market.

This study uses data on individuals' time use from Japan and Korea before and after sudden changes that gave employers incentives to decrease hours of work. The changes in Japan in the early 1990s, and Korea in the early 2000s, show that none of the time freed up from work was used to perform household chores. Instead, it was used mostly for leisure (much as additional television-viewing) in Japan, and mostly for personal maintenance (much as additional personal grooming) in Korea.

The conclusion is that in rich countries today work for pay would not be replaced by unpaid house work if we could cut back on market work. Instead, people would use the freed-up time to enjoy themselves and take care of themselves.

JEL Classification: J22, J11, E24

Keywords: $\quad$ time use, household production, demand shock, macroeconomic effects

Corresponding author:

Daniel S. Hamermesh

Department of Economics

University of Texas

Austin, TX 78712-1173

USA

E-mail: hamermes@eco.utexas.edu

\footnotetext{
* We thank Sandy Black, Steve Trejo and participants in seminars at several universities and other institutions for their comments.
} 
Three-hour shifts or a fifteen-hour week may put off the problem [of little need or desire for market work] for a great while. (Keynes, 1930)

\section{Introduction}

As is quite clear, Keynes' prediction and concern are far from having come to pass. Nonetheless, hours of market work did diminish in the U.S. between 1900 and 1940 (Kniesner, 1976) and dropped sharply from 1950 through 1980 in most of Western Europe (Huberman and Minns, 2007). While Keynes' specific prediction was far from the mark, he got the general direction of change correct. Thus asking what people would do with their extra time if they were confronted with a large decline in market hours remains an interesting question.

The difficulty in answering this question is that changes in individuals'time allocations arise from the interaction of changes in the technology of the production of Beckerian commodities with consumers' preferences for those commodities. That makes it impossible to identify how workers will respond to a permanent cut in market work, or to infer the general equilibrium effects of that cut on time allocation in an entire population by looking at historical changes. Over time the technologies do change and can explain some of the changing allocations of time (Greenwood et al, 2005). Those changes might in turn explain the apparent increase in leisure in the U.S. in the last half century that did not accompany any decline in market work (Aguiar and Hurst, 2007, but see Ramey and Francis, 2009), a change that was mirrored in some European countries (Gimenez-Nadal and Sevilla-Sanz, 2011). But the changing technologies prevent one from inferring preferences for different kinds of non-market activities.

Various authors have considered how time allocation responds to temporary changes in the time available for non-market and market activities. Thus Hamermesh (2002) demonstrated that even an abrupt, fully-anticipated and temporary increase in available time (resulting from a 
switch off summer time) is non-neutral, with a disproportionate fraction of the increase consumed as additional personal maintenance activities, mostly sleep. Burda and Hamermesh (2010) showed that a temporary, but presumably unexpected decrease in market work (resulting from cyclical changes in employment) is disproportionately taken up by increased household production, although Aguiar and Hurst (2011), using data from a shorter time period, but a deeper and long recession, show that increases in household production, personal maintenance and leisure accounted for roughly equal shares of the decline in market work.

No study has examined how individuals' time allocations respond to an exogenous permanent decline in market work, nor has any looked at the general equilibrium effects of such a decline on time allocation. ${ }^{1}$ None could-there have been very few permanent exogenous shocks to market work; and, in any event, the continuing time-diary information required to analyze the impact of these shocks on the distribution of non-market time has rarely been available. A few countries have indirectly imposed changes in hours of work by introducing legislated changes regulating the standard workweek (e.g., France, see Crépon and Kramarz, 2002) or giving union-management negotiators incentives to alter standard hours (e.g., Germany, see Hunt, 1999); but these changes have been small and havenot always been permanent and, in any case, we lack the pre- and post-change data on non-market time to analyze their impacts.

In an effort to reduce work hours, between 1988 and 1997 Japan shortened the standard work week, resulting in a substantial reduction in market work as measured by standard CPStype household surveys offering retrospective reports of work time (Kawaguchi et al, 2008). Quinquennial Japanese time-diary data are available from 1976, allowing us to examine the

\footnotetext{
${ }^{1}$ Gouxet al (2011) examine the impact of the French change in the standard workweek on the labor supply of spouses of workers who were affected by the legislated change. The focus was only on the spouse's hours of market work. Stancanelli andvan Soest (2011) study the impact birthday on time allocations of the discrete jump in incentives to retire in France after one's $60^{\text {th }}$, an incentive that is permanent and well-known to workers while planning the time paths of their allocations of time.
} 
impacts of this shock and to adjust for possible trends in time use that had been occurring. Korea made a similar change in 2004, and the availability of Korean time-diary data from 1999, 2004 and 2009 enables us to study time allocation before the legislative change was proposed and after its effects had time to be realized.

We examine patterns of changes in the allocation of non-market time in the entire population and by gender in these two countries over these time periods. These analyses estimate differences and then double-differencesacross days of the week. They allow us to measure the general-equilibrium effect of the legal changes, in particular, whether and to what extent their impact was spread across alternative non-market uses of time.

\section{The Shocks and the Data}

\section{A. Legislated Changes in Work Hours}

Statutory working hours in Japan had historically been set at 48 per week and 8 per day. In December 1985 a study group organized by the Ministry of Labor published a report that suggested 45 hours per week and 8 hours per day as new statutory working hours. ${ }^{2}$ Following this report the Central Labor Standards Commission, consisting of public, employer and employee representatives, recommended setting standard hours at 46 per week temporarily, followed by 44, and eventually dropping to 40 . The Commission also requested a temporary exemption for small- and medium-sized firms. In accordance with its recommendation, the law was revised in 1987 and implemented from April 1, 1988.

\footnotetext{
${ }^{2}$ The Labor Standard Act (LSA) in Japan prohibits employers from employing workers exceeding daily and weekly statutory working hours, currently set at 40 hours per week and 8 hours per day (LSA Section 32). Employers can set hours worked to exceed these legal limits only under an agreement with a workers' group that represents the majority of employees (LSA Section 36). Overtime under this agreement must be compensated by at least a 25percent wage premium (LSA Section 37).See Sugeno (2002, Chapter 3, Section 5) for an overview of the Japanese legal system on standard hours. Hamaguchi (2004, Chapter 12, Section 2) describes the legal process of reducing the standard hours between 1987 and 1997. Umezaki (2008) also describes the process of the LSA revision based on interviews with two government officials who played central roles in it.
} 
This revision in the law immediately set standard hours at 46 per week. An additional revision in December 1990 further reduced standard hours to 44 from April 1, 1991. The Labor Standards Act was further revised in 1993 to implement 40 hours per week beginning in April 1994. In this reduction process, exemptions were given to industries with long work hours and smaller establishment sizes. These exemptions ended by March 1997, by which time the standard had become 40 hours per week uniformly across industries and establishment sizes with only a few exceptions requiring agreement between management and the union representing its workers. $^{3}$

Standard hours in Korea had become 44 per week in all workplaces (Kim and Kim, 2004) by 1991. After the Asian economic crisis in November 1997, reducing statutory weekly working hours from 44 to 40 began to be discussed by the Korean Economic and Social Development Commission. In October 2000 the Commission announced the "Basic Agreement on Work Hour Reduction,” which included: 1) A reduction in work hours to 40 hours per week and 2000 hours per year; and 2) Gradual adoption depending on industry and firm size. In July 2002 the five-day workweek was first officially adopted in the banking and finance sector. In August 2003 the law indicating the schedule for adoption of the five-day workweek passed Congress.

The law mandated a phase-inof a five-day workweek, with workplaces of more than 1000 employees becoming covered in July 2004, phasing down to workplaces with between 20 and 49 employees by July 2008 (and with smaller workplaces still not covered today). The government provided some financial incentives for firms that adopted the five-day workweek before it became mandatory on them, and overtime regulations were also altered to encourage adoption.

\footnotetext{
${ }^{3}$ Exceptions apply to employees in commerce and service industries in establishments that usually employfewer than ten workers.
} 
A fair conclusion from all this is that the movement toward reduced workweeks in Korea was becoming partly effective in 2004 and was very widespread, perhaps nearly universal by 2009 .

We view these two legislated changes as imposed shocks that reduced the demand for market hours. It is quite possible that the impetus for the legislation was a generalized desire to work fewer hours, and that the legislation merely embodied people's preferences and allowed the economy to move to a new equilibrium in which coordination among employers and workers allowed fewer hours of market work per capita. For our purposes, whether the legislation was the ultimate or only the proximate cause of a decline in hours of work per capita is irrelevant: Whether the result of a demand shock or because collective preferences allowed a one-time drop in hours of market work, the responses of different types of non-market hours demonstrate how the aggregate of individuals react to an increase in the time available outside the market.

\section{B. Time-Diary Data in Japan and Korea}

The Japanese Time Use Survey (JTUS) is conducted by the Bureau of Statistics every five years, with the first survey conducted in 1976. The survey initially targeted the entire population age 15 or older, but the JTUS expanded its coverage to individuals age 10 or older from 1996. Each respondent fills out time diaries for two consecutive days, reporting their activities in ten-minute (1976) or fifteen-minute (1986-2006) intervals. ${ }^{4}$ The number of precoded categories of activity was 17 in 1976, 19 in 1986, and 20 in 1991 and after. The sample is nationally representative with individual survey weights, but it has decreased in scope from about 190,000 persons in 1976 to about 175,000 in 2006. The 1976 surveys were conducted over seven consecutive days in October. The1986 and subsequent surveys were fielded over nine-day periods including two weekends in October.

\footnotetext{
${ }^{4}$ The 1981 survey hada different format from those in other years. Each respondent directly filled out time spent in each activity in a single day. Perhaps because of this format, the figures for 1981 are not comparable to those from other years, and because of their non-comparability we do not use them.
} 
The Korean Time Use Survey (KTUS) is conducted by the National Statistical Office every five years, with the first survey conducted in 1999. The survey targets the entire population aged 10 or older and has a remarkably high response rate (for time-diary surveys), above 90 percent. Each respondent fills out time diaries for two consecutive days, reporting activities in ten-minute intervals. The number of possible activities was 125 in 1999, 137 in 2004 and 144 in 2009. The sample is nationally representative with individual survey weights, but it decreased from over 40,000 observations in 1999 to barely 20,000 in 2009. The 1999 and 2004 KTUS were conducted over ten consecutive days early in September. The 2009 survey was also fielded over ten-day periods, but, because of concerns about potential seasonality in time use, it was conducted in both March and September.

The JTUS for 1976 and 1986 clearly precede the shock to hours of work. The 1996 and subsequent surveys are clearly post-shock. The difficulty is with the 1991 survey, which was fielded after the legal changes but before they were fully or widely effective. In most of the discussion we thus treat 1991 as pre-shock, 1996-2006 as post-shock. By chance the timing of the KTUS is almost perfect for the purposes of this study: The first survey precedes any possible effects of the cut in demand for market work, the second occurs as the cut might have begun to have some impact, and the third takes place after the changes had mostly been realized.

The time-diary surveys from Korea, and even that from Japan, allow respondents to list far too many different activities for purposes of analyzing the impacts of the legislated changes. We need to combine the basic activities into tractable aggregates. We take the fourfold breakdown: Market work (M); household production (H); tertiary (chiefly personal maintenance) activities (T) and leisure (L), and classify each basic activity in each country into one of these. Market work includes paid employment or self-employment, unpaid employment, 
job search, commuting and schooling/studying. Household production consists of those activities for which one could find market substitutes (as initially proposed by Reid, 1934). Tertiary activities are those activities, including sleep and eating, that people must typically do at least some of on most days; and leisure activities are those that do not pay, that could not be contracted out and that are not biologically required. For both countries a very few activities were not classifiable, and we prorate the few minutes included in these across the four aggregates in proportion to the time spent in each aggregate. ${ }^{5}$ The classifications of the 20 (9) primary subaggregates in Japan (Korea) are shown in the Appendix.

We use data for Japan and Korea because those are the only two countries we know of that instituted this type of legislated change and that collected large-scale time-use surveys shortly before and shortly after the introduction of such legal changes. Whether the effects that we uncover here would also be observed in response to declines in hours of market work in rich Western economies is not clear. We cannot know how large or even what the responses would be at the current margins of time use. Ignoring issues of the comparability of time-diary surveys across countries, it is the case, however, that the allocations of time in these four aggregates are not that different in two major Western countries, Germany and the United States, from what we observedin Japan and Koreaimmediately before the legislated changes. As Table 1 shows, the main difference is that hours of market work are lower in Germany and the U.S., while hours of household production are greater than in Japan and Korea. ${ }^{6}$

\footnotetext{
${ }^{5}$ In Korea the number of prorated minutes was 19, 13 and 19 in 1999, 2004 and 2009 respectively. In Japan the total minutes prorated were somewhat greater: 34 in 1976, 34 in 1986, 34 in 1991, 48 in 1996, 53 in 2001 and 50 in 2006.

${ }^{6}$ The calculations for Germany are based on the Zeitbudgeterhebung2001/02, time diaries kept on three separate days by over 12,000 Germans http://www.destatis.de/jetspeed/portal/cms/Sites/destatis/Internet/DE/Presse/abisz/ Zeitbudgeterhebung.psml. Those for the U.S. are based on public-use files of the American Time Use Survey (Hamermeshet al, 2005) containing time diaries for single days kept by nearly 50,000 individuals. All the summary statistics in Table 1 are computed using sampling weights.
} 


\section{Effects on Aggregate Market Work Time}

Throughout these sections we use all the available complete time diaries—-for Japan from 1976, 1986 and the subsequent quinquennia, and for Korea from 1999, 2004 and 2009. This allows us to account for possible aggregate trends. In much of the work we present the results for all days aggregated, then for weekdays, Saturdays and Sundays separately.We use data covering all sample respondents ages 15 and older, and the results use sampling weights that account for population characteristics and variations in sample sizes across days of the week.

Figures 1-3 show minutes of work in the entire week and on the three types of day, for all the sample respondents and separately by gender. The statistics here and in the subsequent figures and tables reflect the experience of the representative Japanese/Korean in the particular demographic group on the particular day(s) of the week. The left-hand side of the upper panel in Figure 1 supports the notion that there was a one-time decrease in hours of work per worker in Japan after the legal changes governing the standard workweek. In the three quinquennia after the imposed changes the average adult worked 37 minutes less on average than in 1991. The bottom panel shows that in Korea the changes in work-hours from 1999, before the legal changes, through 2004, when they were just becoming effective, to 2009, by which time they had been in effect nearly five years, are on average the same as in Japan—a drop of 37 minutes over the decade.

These declines in market work are not the result of correlations of timing of the legislated changes with declines in labor demand induced by macroeconomic changes. In Japan in 1986 the aggregate unemployment rate was 2.8 percent; in 1996, 2001 and 2006 it was 3.4 percent, 
5.0percent and 4.1 percent respectively. In Korea the aggregate unemployment rate was 6.3 percent in 1999 (immediately after the Asian crisis), but only 3.6 percent in $2009 .^{7}$

Given that the legislative changes affect the marginal cost of an hour of male labor more than that of female labor, because men were more likely to have worked more than forty hours per week, we expect larger decreases in market work among men than women. This is true in the aggregate in Korea: Female work time dropped by 29 minutes per representative day between 1999 and 2009, while male work time decreased by 44 minutes per day. The same thing also occurred in Japan: Between 1991 and the average of 1996-2006 average daily work time decreased by 43 minutes among men but only 31 minutes among women.

The three sets of graphs in the right-hand panels of Figures 1-3 present the mean minutes of work by type of day in total and separately by gender for each of the years for which we have time diaries. In Japan there was a decrease in work time on weekdays between 1991 and 2006 of 42 minutes per day, of which 22 minutes occurred between 1996 and 2006 . But the decline on weekends was much larger, averaging 87 minutes (on a smaller base) on Saturdays (of which 46 minutes happened by 1996), although only 17 minutes on Sundays. The concentration on weekends was even more pronounced in Korea: Between 1999 and 2009 there was a 16-minute daily decline in minutes of work on weekdays, but a 104-minute decline on Saturdays, and a 62minute drop on Sundays.

The hebdomadal distribution of changes in work time by gender reflects men's greater representation among weekend workers. In Japan, for example, men’s (women’s) average work time on weekdays declined by 38 (29) minutes between 1991 and the average of 1996-2006. On Saturdays, however, it declined by 86 (52) minutes, while on Sundays it dropped by 22 (11) minutes. The same pattern appears in Korea: The analogous declines (between 1999 and 2009)

${ }^{7}$ http://stats.oecd.org/Index.aspx?DatasetCode=ALFS_SUMTAB 
were 18 (14) minutes on weekdays, 131 (77) minutes on Saturdays, and 74 (49) minutes on Sundays.

The statistics summarized in Figures 1-3 do not, of course, account for demographic changes that occurred over time in the two countries. It is unlikely that our general conclusions would be altered if we took demographics into account, but it is worthwhile adjusting for all the observables that can be viewed as affecting patterns of time use and as probably exogenous to adult time use. In Korea this means adding variables describing: Years of schooling, metropolitan/non-metropolitan location and age. In Japan we add covariates for educational attainment and age. ${ }^{8}$

Tables $2 \mathrm{~J}$ and $2 \mathrm{~K}$ (a tabular notation used in the remainder of this study) describe the results of OLS estimates of regressions describing minutes of market work that pool all the available years of time diaries for each country and that add indicators for each survey year. ${ }^{9}$ The left-hand side of each table shows the results for the representative day of the week, in total and then separately by gender; the right-hand side lists the estimates for equations fitted separately for weekdays, Saturdays and Sundays. Given our concentration on quinquennial changes, we only list the parameter estimates for the year indicators (along with their standard errors and the $\mathrm{R}^{2}$ for each equation).

The estimates support the conclusions from the sample means. They suggest: 1) The total effect is around 18 minutes in both Japan and Korea; 2) The effects are much larger among men than among women, a 32-minute decline in working time on the representative day among

\footnotetext{
${ }^{8}$ For Japan, Kuroda (2010) implemented essentially the same exercise, but held employment status and the type of employment (full-time or part-time) constant. We do not include these as conditioning variables, since they are affected by the reduction of the standard hours and, indeed, themselves reflect the outcomes in which we are interested.

${ }^{9}$ There are sufficiently few zeros in the four aggregates that using tobit estimation adds very little to the analysis.
} 
Korean men, and a 25-minute decline among Japanese men. There is essentially no decline among Korean women, and only a 10-minute decline among Japanese women; and 3)Adjusting for these few demographic characteristics, even the distributions of the effects of the legislation by day of week and gender seem quite similar in Japan and Korea. In both countries the changes on weekdays are small and perhaps even non-existent. The biggest declines in daily minutes of work are on Saturdays and among men, averaging over 1 hour in Japan, and nearly two hours in Korea. The impacts among women show roughly 40-minute declines on Saturdays. The effects on Sundays in Korea are about half of the size of those on Saturdays; and in Japan they are essentially zero among women and less than 15 minutes among men.

While the estimates in Tables 2 account for covariates, they cannot account for any unobservable heterogeneity among the samples' respondents. We can, however, take advantage of the sample design, in which respondents were interviewed on two consecutive days, with some being interviewed on Friday and the next Saturday, and others interviewed on Sunday and the next Monday, to examine the potential role of unobservables.

Restricting the samples to those individuals who were interviewed on one weekday and one weekend day, and using the result that a disproportionate share of the decline in market work appears to have occurred on weekends, we can write market work time as:

$$
\mathrm{M}_{\mathrm{itd}}=\alpha \mathrm{X}_{\mathrm{it}}+\beta_{1} \mathrm{P}_{\mathrm{it}}+\beta_{2} \mathrm{SA}_{\mathrm{itd}}+\beta_{3} \mathrm{P}_{\mathrm{it}} \mathrm{SA} \mathrm{A}_{\mathrm{itd}}+\beta_{4} \mathrm{SU}_{\mathrm{itd}}+\beta_{5} \mathrm{P}_{\mathrm{it}} \mathrm{SU}_{\mathrm{itd}}+\mu_{\mathrm{it}}+\varepsilon_{\mathrm{itd}},
$$

where i denotes an individual, t denotes a year, and d denotes a day, Friday through Monday; SA is an indicator for Saturday, SU for Sunday, and with separate indicators for Years t=1986, 1991, 1996, 2001 and 2006 in Japan,and t=2004 and 2009 in Korea. The individual-year fixed effects, $\mu_{\mathrm{it}, \mathrm{c}}$ apture person-specific unobserved determinants for market hours that do not vary across days 
within the year the person is interviewed.If the results above are correct and are not simply produced by unobservable factors, we should observe $\beta_{3}, \beta_{5}<0$ after allowing for individual effects — within-person differences between work time on Friday and Saturday, and Sunday and Monday, should be greater after the legislated change. If the results in Tables 2 are correct, that should be especially the case for Friday-Saturday differences, less so for Sunday-Monday differences, so that $\beta_{3}<\beta_{5}$.

Table 3 presents the estimates of equation (1). We interact indicators for Saturday and Sunday with indicators for all years other than the initial year in each sample. If the legislated change decreased market work mainly on weekends, we would expect the parameter estimates on these interactions to become more negative around the time of the change. This is exactly what we observe. The estimates demonstrate that the implications drawn from Figures 1-3 and Tables 2 do not arise from correlated unobservables. In both countries within-person differences in market work time on Saturdays compared to Fridays around and immediately after the changes in hours laws were much greater than those before the legislated changes. There is no trend in the interactions of Sunday with year, suggesting that there was essentially no change in the difference in time spent in the market by the typical person between Sundays and Mondays. Moreover, all of these changes are larger among men than women.

The descriptive statistics, the parameter estimates describing the entire samples, and the within-person comparisons across weekdays and weekends all show sharp declines in aggregate work time during and immediately after the period when the legislative changes raised employers' costs of overtime work. The declines were concentrated disproportionately among men and on weekends. They suggest that the policy change caused declines in market work economy-wide. 


\section{Effects on the Aggregate Allocation of Non-Market Time}

Comparing 1999 and 2009 in Korea, there was an 11 percent decline in the average daily minutes of market work in the entire adult population (both workers and non-workers). Comparing 1991 to 1996-2006 in Japan, the decline was also 11 percent. Adjusting for a number of demographic changes, the aggregate decreases in average daily market work time were about 6 percent in each country. How did these sudden declines alter the average person's allocation of time among the other three main categories of time use-home production $(\mathrm{H})$, tertiary activity (T) and leisure (L)? To answer this question we present the same types of calculations here as in Figures 1-3 and Tables 2, showing the amounts of time allocated to these activities before and after the drop in work time.

Figures 4-6 depict the time that the average adult male and female in Japan and in Korea allocated to $\mathrm{H}, \mathrm{T}$ and $\mathrm{L}$ on a representative day of the week. The central conclusion from these summary figures is that there is little evidence that the extra time made available by the permanent negative shock to market work time was taken up in household production. In Japan the increase in $\mathrm{H}$ among men that occurred from 1976 to 1991 continued at roughly the same rate, although the decrease in $\mathrm{H}$ among women that proceeded during that period did cease. In Korea there was a 4-minute increase in $\mathrm{H}$ between 1999 and 2009 among men, but an 18-minute decline among women.

In Korea both men and women allocated the time gift essentially one hundred percent to increases in the time spent in tertiary activities; there was essentially no change in leisure time. In Japan the split was much different, with tertiary activities increasing, but with leisure activities accounting for around half of the time saved in market work Given the differences between the two countries in how basic activities might be classified, one should not make too much of the 
differential changes in $\mathrm{T}$ and $\mathrm{L}$ between the two. The most important inference from these summary statistics is that very little of the time gift in either nation was used to substitute household production for market work, despite the relatively (by international standards) small amount of time initially allocated to household production.

To check whether the changes in the means are caused by changing demographics, Tables4 reportestimates of the same equations for $\mathrm{H}, \mathrm{T}$ and $\mathrm{L}$ that we reported in Tables 2 for M.Taking the aggregate decreases in market work in Japan (Korea) of 18 (18) minutes overall, 25 (32) minutes among men and $10(-1)$ minutes among women, this is an accounting exercise that distributes these drops among the other major uses of time after accounting for demographic changes that might have generated them. In Japan nearly $2 / 3$ of the additional time was consumed as leisure, with almost no change in total time spent in household production. In Korea the drop in market work was allocated more than 100 percent to increases in T: Time spent in both $\mathrm{H}$ and $\mathrm{L}$ decreased in Korea.

Changes in the Japanese aggregates mask differences by gender. Men increased their time in household production, while women decreased theirs. Nonetheless, the main use of the time gift by both sexes was in additional leisure. In Korea both men and women increased their time in tertiary activities; but among men there was no change in $\mathrm{H}$, while $\mathrm{L}$ decreased somewhat; among women the absence of a decline in market activity was accompanied by a large increase in $\mathrm{T}$ and shifts away from $\mathrm{H}$ and, to a lesser extent, $\mathrm{L}$.

As a check on these results we substituted $\mathrm{H}, \mathrm{T}$ and $\mathrm{L}$ sequentially for $\mathrm{M}$ in Equation (1), in order to examine whether the patterns of changes in non-market time use that we have documented are robust to the inclusion of individual/year effects. For Japan the results corroborated those in Tables 4J, with a disproportionate share of the change occurring on 
Saturdays and being concentrated on leisure activities. For Korea the majority of the change was also on Saturdays, although some of the freed time was spent in leisure as well as tertiary activities. The crucial result, however, is that with this check too almost none of the extra time was spent in household production.

It is worthwhile disaggregating these changes to discover what particular leisure activities (in Japan) and tertiary activities (in Korea) were consumed more intensively after the shock to market work time. In Japan 8 of the roughly 12 minutes of additional daily leisure (and thus nearly half of the time freed up by the legislation) were allocated toward additional television viewing. Of the 44 minute increase in T between 1999 and 2009 in Korea, only 3 minutes were accounted for by increased time spent sleeping or napping; and time spent eating with one's family actually decreased by 2 minutes. Over half of the time gift was allocated toward increases in personal hygiene and grooming, with another fifth allocated to increases in snacking and drinking.

One clear result stands out from these two natural experiments: They did not lead to a substitution of household production for market time in the aggregate. While the gift of time was consumed in Japan mostly as additional leisure, and in Korea as additional tertiary time, in neither did it generate what might be considered as productive increases in time. By inference, if shocked into working less, participants in a modern economy will use their time gift to enjoy more leisure or recuperate from the stresses of daily activities.

\section{Conclusions and Implications}

It is impossible to infer from historical information on time use how people would react to freedom from work: Any long-term change in time-use patterns is determined endogenously through changing incentives produced by changing household technology and changing returns 
to market work. To circumvent this simultaneity we have relied upon sudden and sharp changes in labor demand generated by discrete and permanent legislated cuts in the standard workweek that gave employers a strong incentive to shorten hours per worker.

Examining the impacts of the legislated changes in the aggregate, in both Japan and Korea,we find that the legislation caused declines in market work. In Japan the freed-up hours were used mainly in what we have classified as leisure activities, in Korea mainly in what we have called tertiary activities. In neither country was the cut in market work met by anaggregate increase in household production. This result is striking and was not produced by any unobservable heterogeneity among the people in our samples.

Assuming that technical change in the intermediate future makes an hour of household production relatively less desirable, as it has over the past century, our results suggest that it is unlikely that people will spend more time in those activities. They suggest instead that at current margins additional tertiary time and leisure are more enjoyable than additional time in household production, so that those changes in technology would instead result in expansions along those other margins. ${ }^{10}$

\footnotetext{
${ }^{10}$ This observation is not necessarily inconsistent with the hypothesis that international differences in time spent in market work are offset by full substitution toward home production because of differences in service prices (Freeman and Schettkat, 2005).
} 


\section{REFERENCES}

Mark Aguiar and Erik Hurst, "Measuring Trends in Leisure: The Allocation of Time over Five Decades,” Quarterly Journal of Economics, 122 (Aug. 2007): 969-1006.

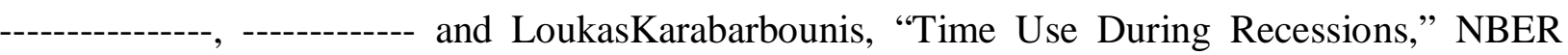
Working Paper No. 17259, July 2011.

Michael Burda and Daniel Hamermesh, "Unemployment, Market Work and Household Production,” Economics Letters, 107 (Jan. 2010): 131—33.

Bruno Crépon and Francis Kramarz, "Employed 40 Hours or Not Employed 39: Lessons from the 1982 Mandatory Reduction of the Workweek," Journal of Political Economy, 110 (Dec. 2002): 1355-89.

Richard Freeman and Ronald Schettkat, “Jobs and Home Work: Time-Use Evidence,” Economic Policy (Jan. 2005): 5-50.

José Gimenez-Nadal and AlmudenaSevilla-Sanz, "Trends in Time Allocation: A Cross-Country Analysis," University of Oxford, Department of Economics, Discussion Paper No. 547, 2011.

Dominique Goux, Eric Maurin and Barbara Petrongolo, "Worktime Regulations and Spousal Labour Supply,” IZA Discussion Paper No. 5639, 2011.

Jeremy Greenwood, AnanthSeshadri and Mehmet Yorukoglu, "Engines of Liberation,” Review of Economic Studies, 72 (Jan. 2005): 109-33.

Keiichiro Hamaguchi, Rodo Ho Seisaku (Policies on Labor Acts). Kyoto: MineruvaShobo, 2004(in Japanese).

Daniel Hamermesh, "Timing, Togetherness and Time Windfalls," Journal of Population Economics, 15 (Nov. 2002): 601-23.

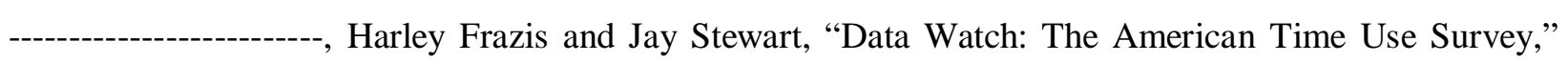
Journal of Economic Perspectives, 19 (2005): 221-232.

Michael Huberman and Chris Minns, “The Times They Are Not Changin’: Days and Hours of Work in Old and New Worlds, 1870-2000," Explorations in Economic History, 44 (Oct. 2007): 538-67.

Jennifer Hunt, “Has Work-Sharing Worked in Germany?” Quarterly Journal of Economics, 114 (Feb. 1999): 117-48. 
Daiji Kawaguchi, Hisahiro Naito and Izumi Yokoyama, "Labor Market Responses to Legal Work Hour Reduction: Evidence from Japan,” ESRI Discussion Paper No. 202, Tokyo, Cabinet Office, ESRI, December 2008.

John Maynard Keynes, "Economic Possibilities for Our Grandchildren," 1930, reprinted in Essays in Persuasion. New York: Norton, 1963.

Sung-teak Kim and Wonshik Kim,Workhour Reduction and Policy Issues, Seoul: Korea Labor Institute, 2004.

Thomas Kniesner, "The Full-Time Workweek in the United States, 1900-1970," Industrial and Labor Relations Review, 30 (Oct. 1976): 3-15.

Sachiko Kuroda, "Do Japanese Work Shorter Hours than Before? Measuring Trends in Market Work and Leisure Using the 1976-2006 Japanese Time-use Survey,”Journal of theJapanese and International Economies, 24 (Dec. 2010): 481-502.

Valerie Ramey and Neville Francis, "A Century of Work and Leisure," American Economic Journal: Macroeconomics, 1 (July 2009): 189-224.

Margaret Reid, Economics of Household Production. London: Chapman and Hall, 1934.

Elena Stancanelli and Arthur van Soest, "Retirement and Time Use in Couples: A Regression Discontinuity Approach,” Unpublished paper, Université de Cergy-Pointoise, 2011.

Kazuo Sugeno, Japanese Employment and Labor Law.Durham, NC: Carolina Academic Press, 2002.

Osamu Umezaki, "Rodokijunho No 1987 NenKaiseiWoMeguruSeisaku Katei” (“The Policy Process in the 1987 Revision of the Labour Standards Law: An Attempt to Analyze by the Oral History Method”), Japanese Journal of Labour Studies, 579 (Oct. 2008): 66-76, (in Japanese). 


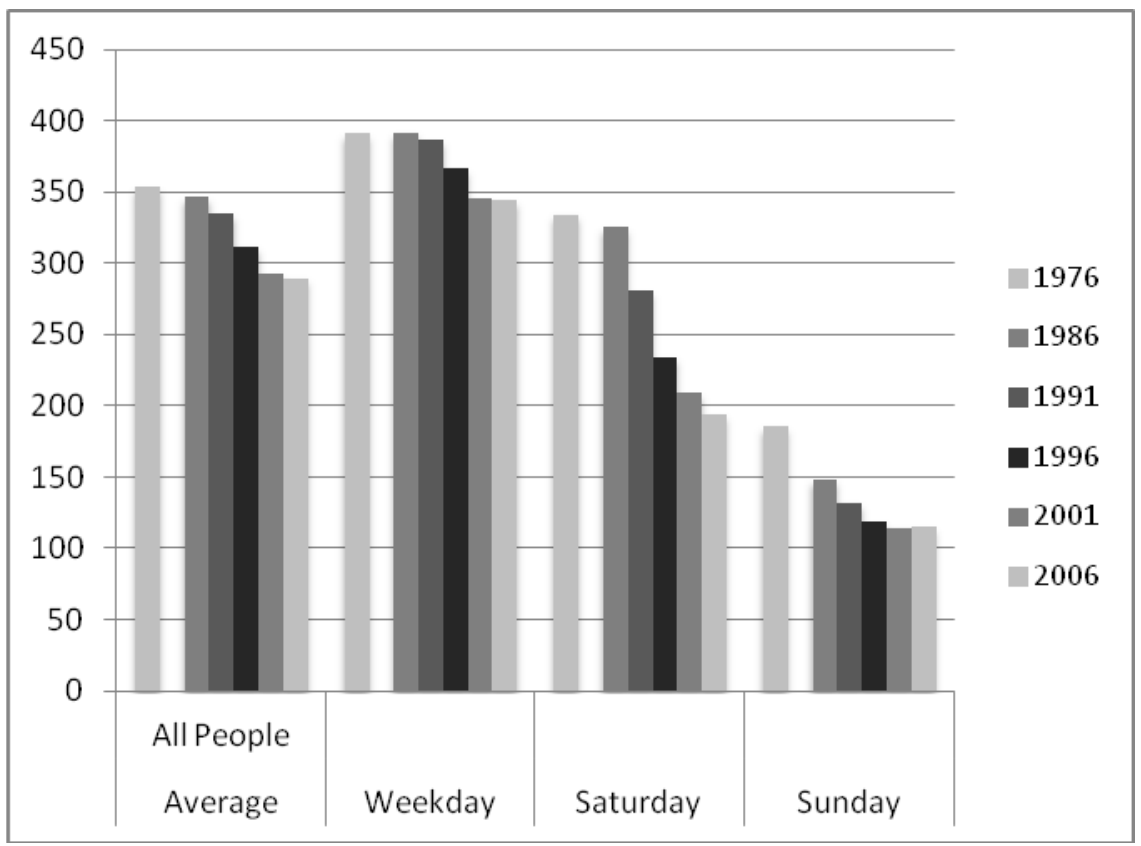

a. Japan

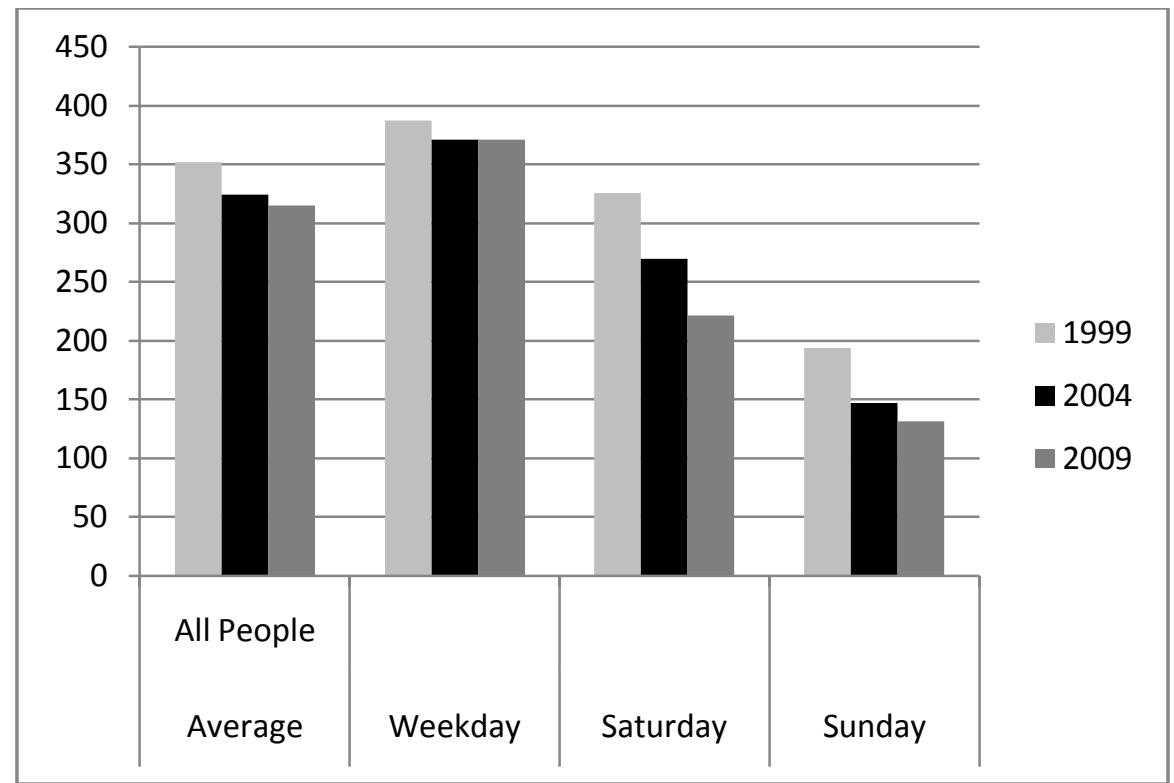

b. Korea

Figure 1. Market Work, Adult Population 


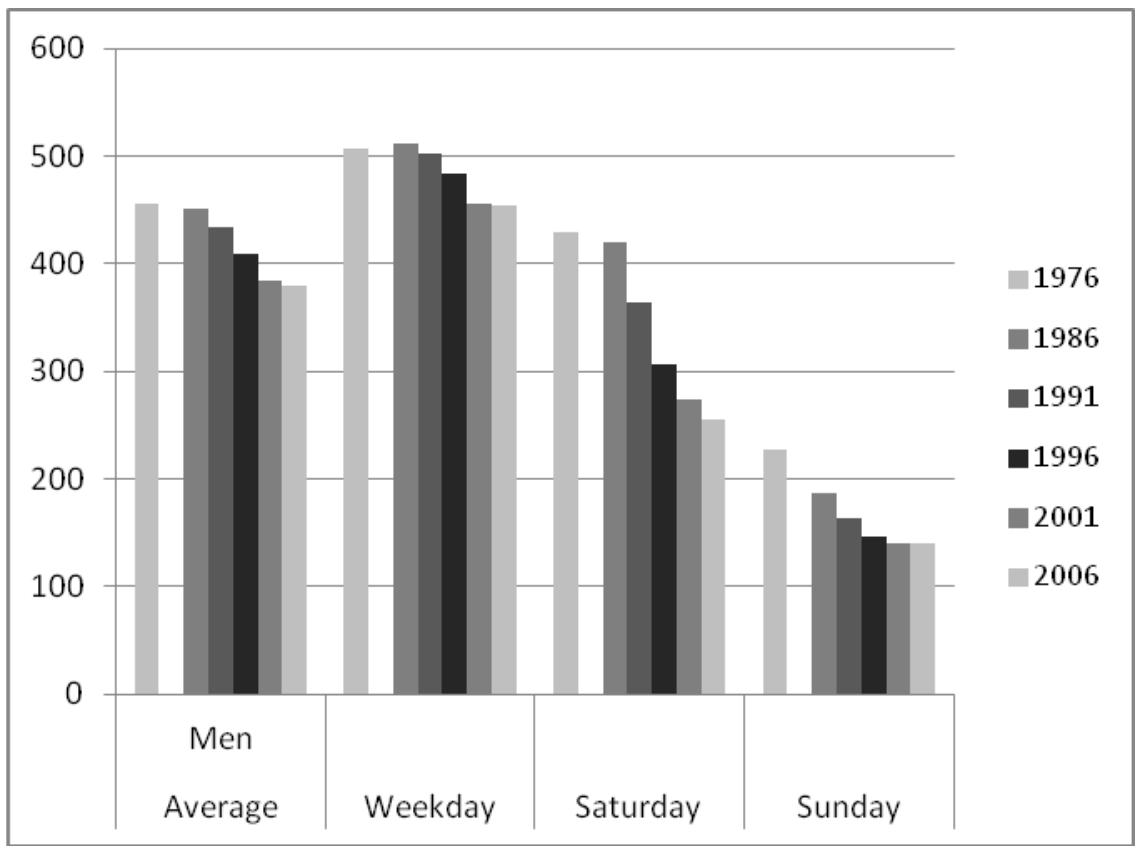

a. Japan

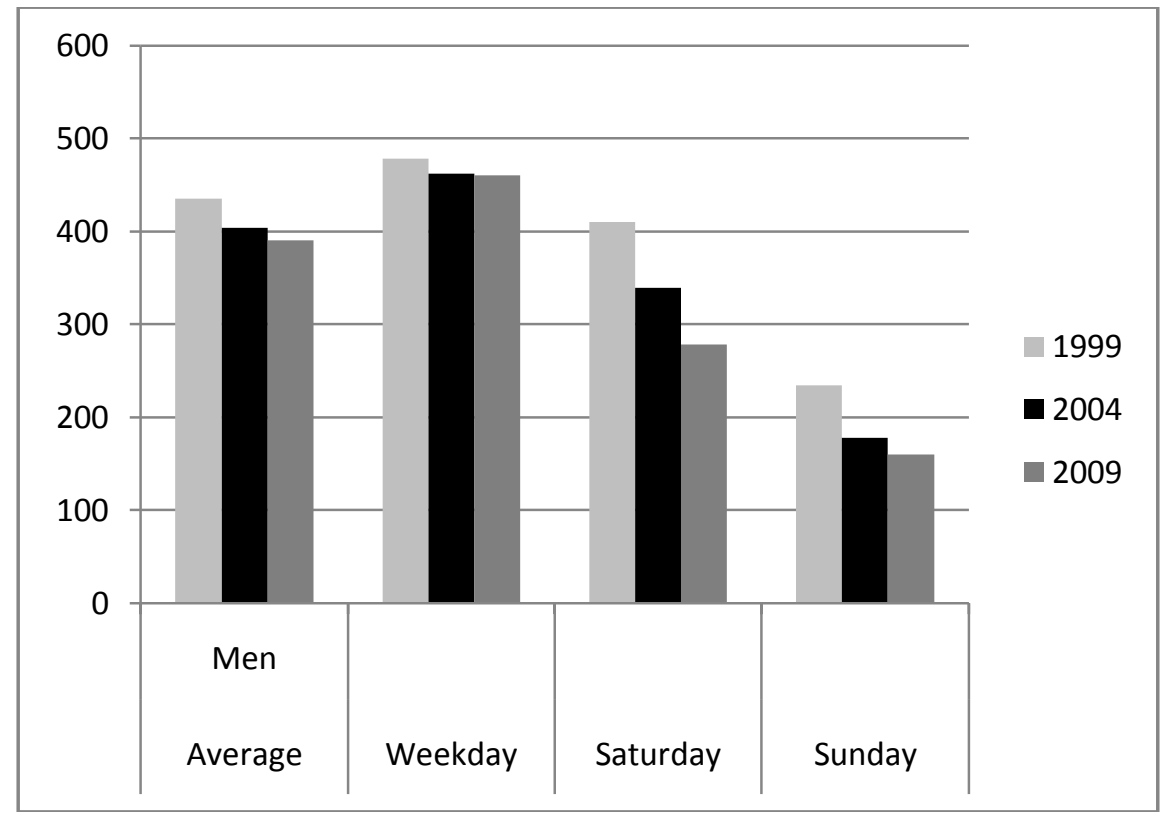

b. Korea

Figure 2. Market Work, Adult Men 


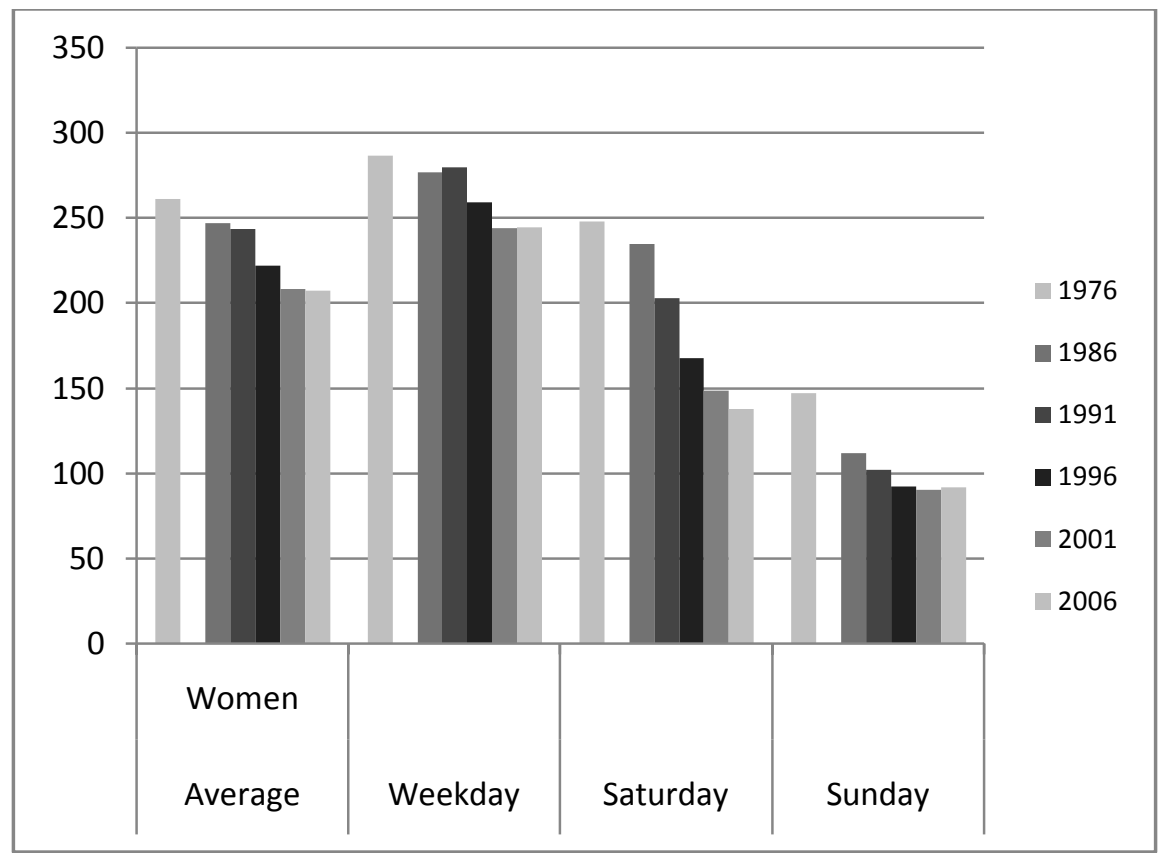

a. Japan

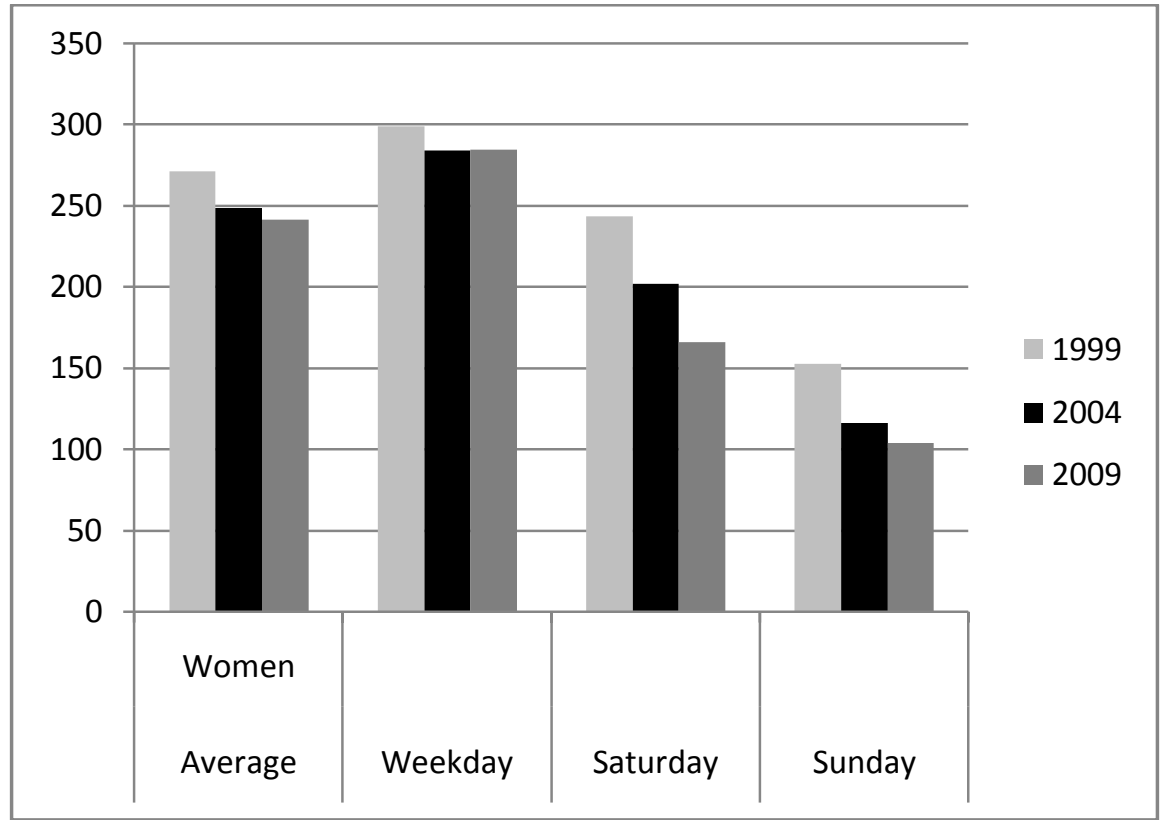

b. Korea

Figure 3. Market Work, Adult Women 


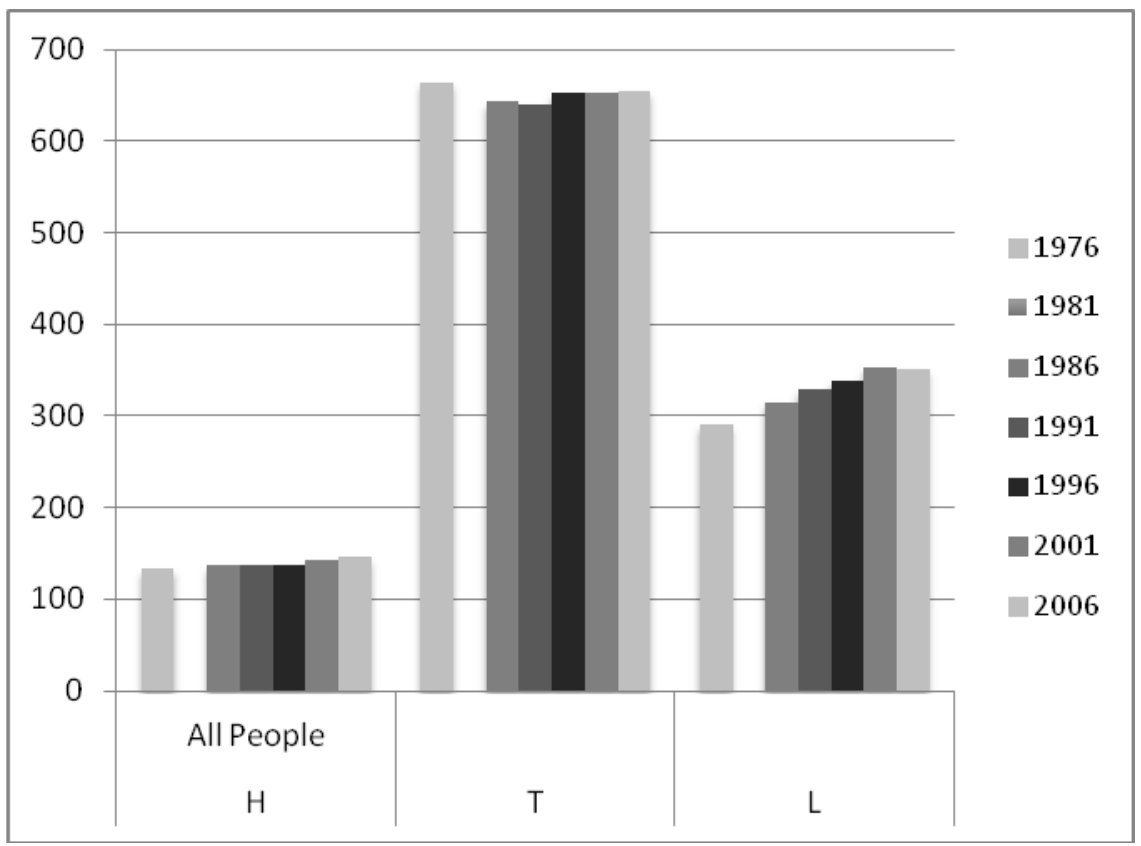

a. Japan

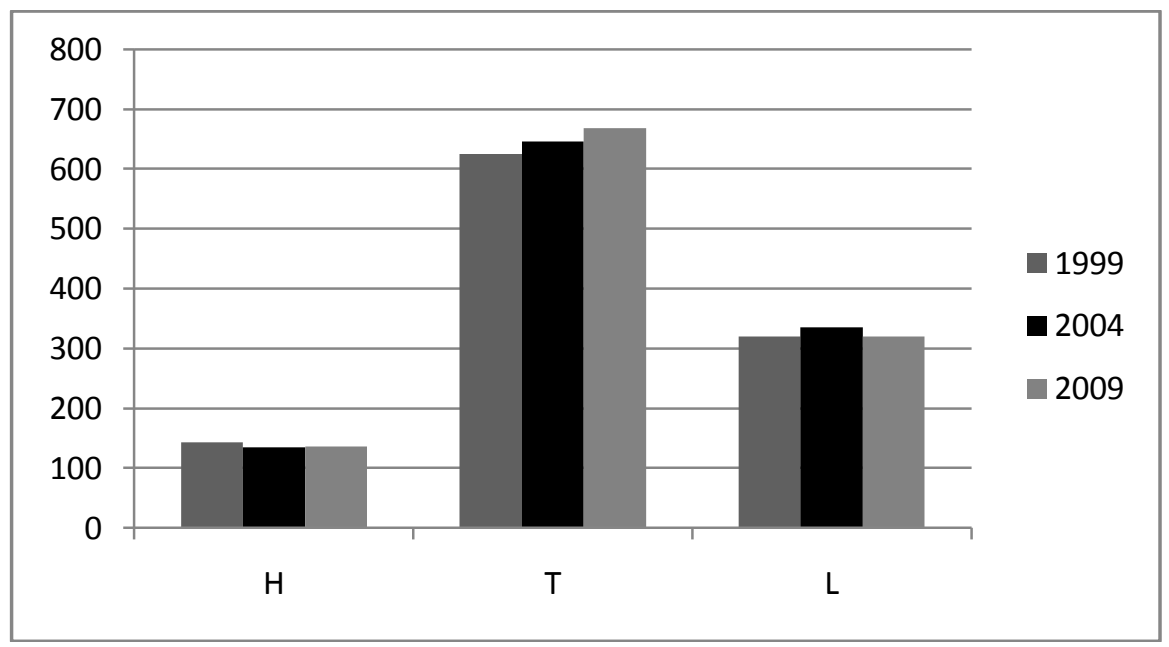

b. Korea

Figure 4.Distribution of Non-Market Time, Adult Population 


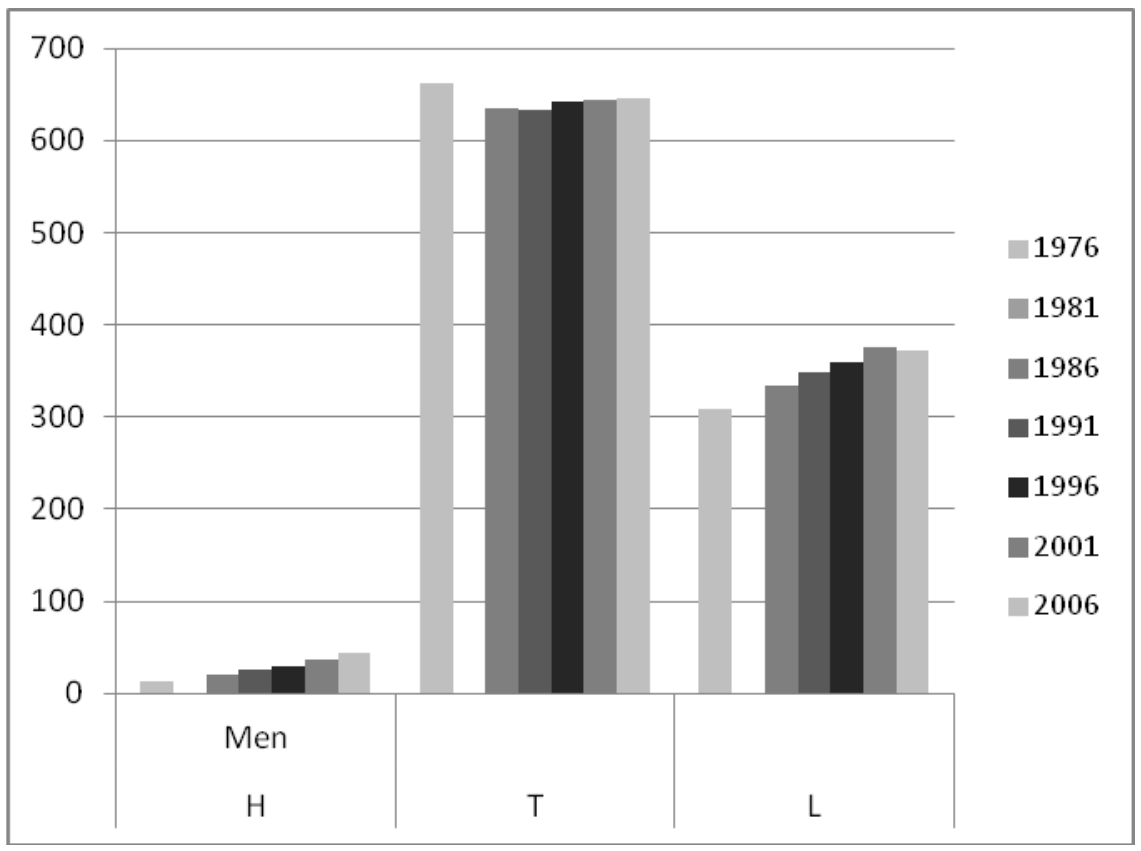

a. Japan

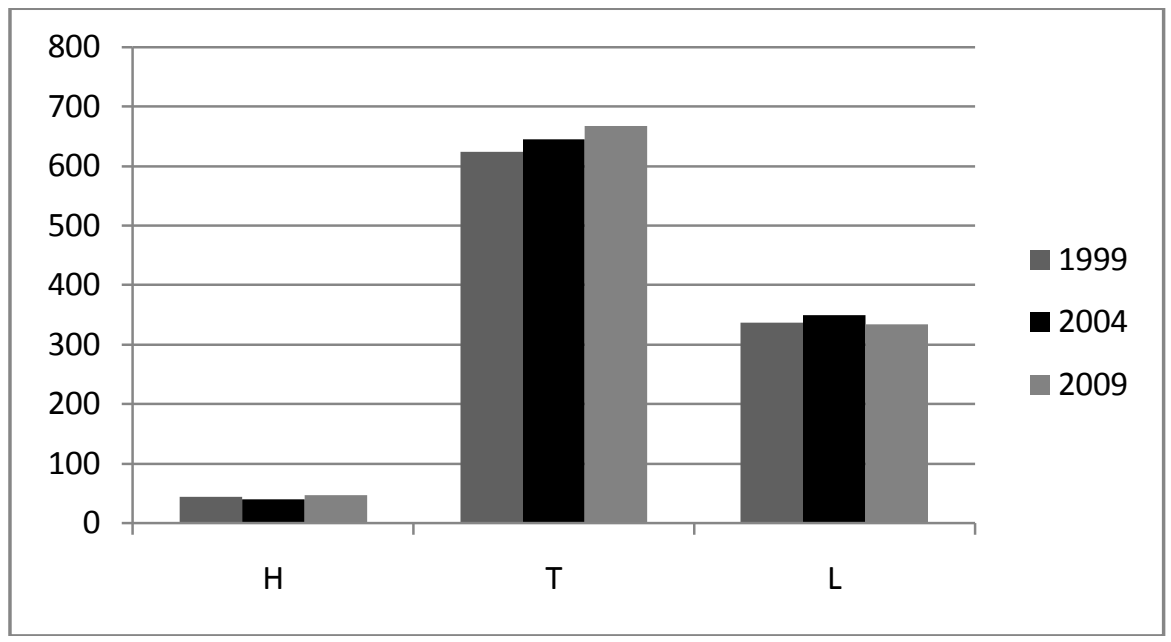

b. Korea

Figure 5.Distribution of Non-Market Time, Adult Men 


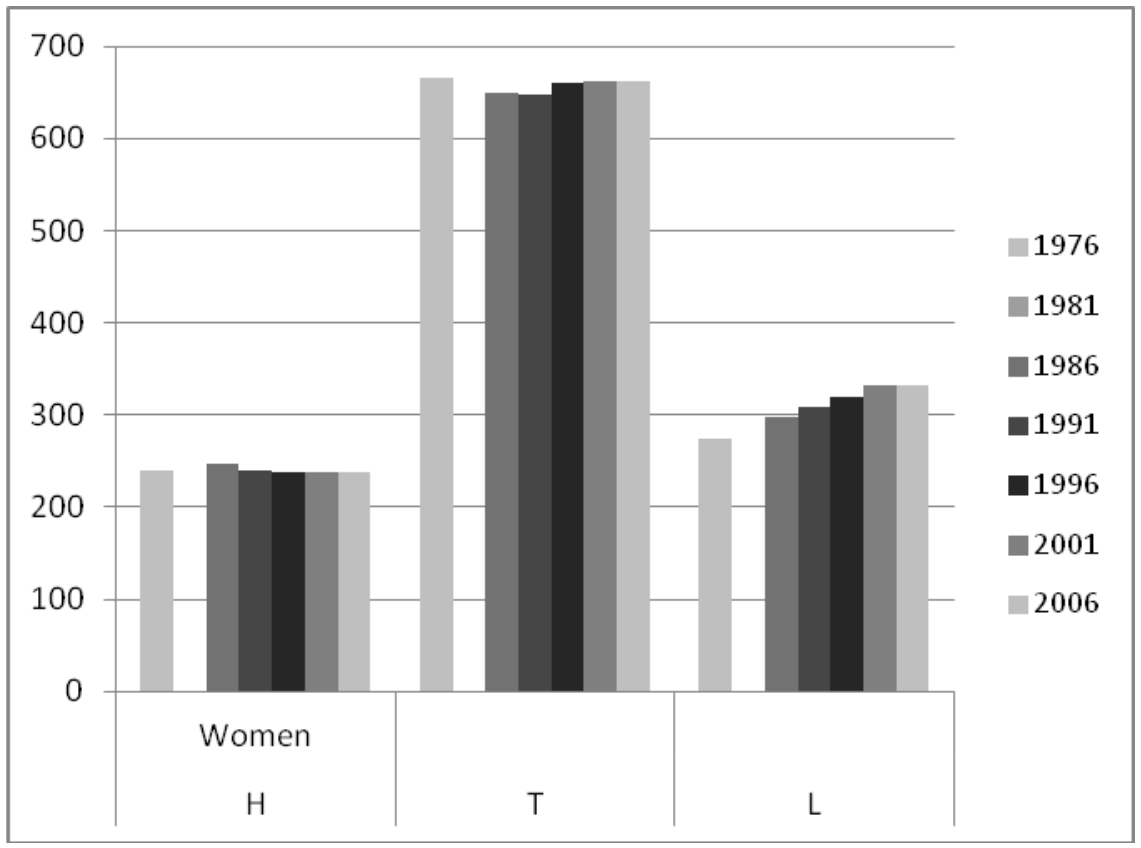

a. Japan

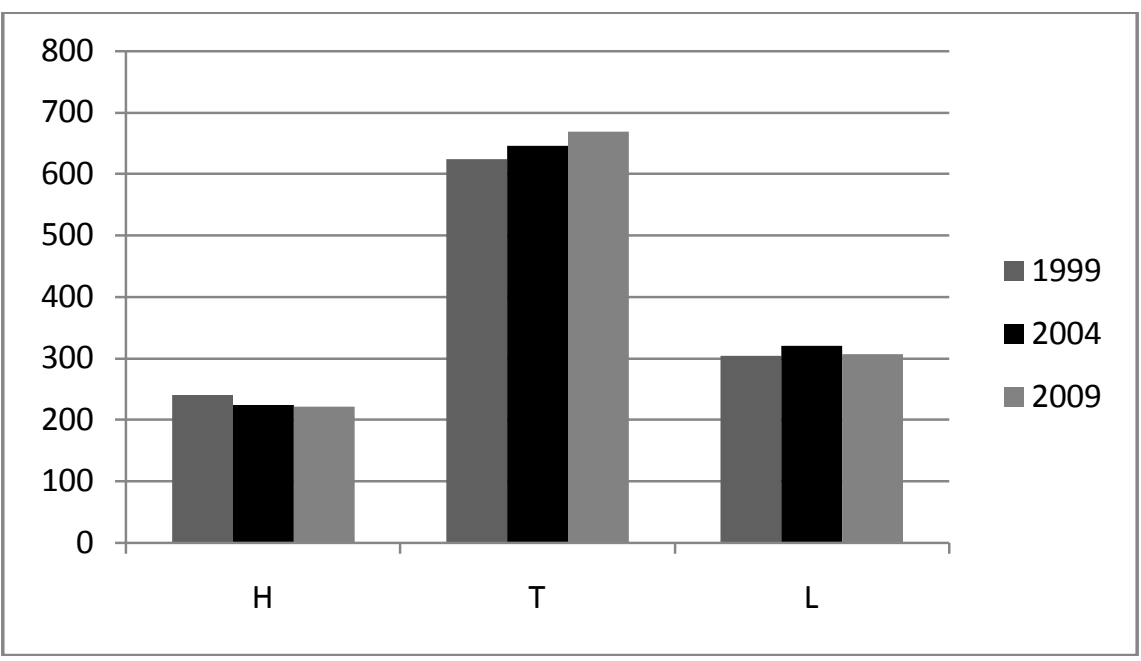

b. Korea

Figure 6.Distribution of Non-Market Time, Adult Women 
Table 1.Breakdown of Time Use in Japan, Korea, Germany and the U.S. (minutes per representative day)

\begin{tabular}{lcccc}
\hline \multicolumn{1}{c}{ Economy and year: } & $\begin{array}{c}\text { Japan } \\
\mathbf{1 9 8 6}\end{array}$ & $\begin{array}{c}\text { Korea } \\
\mathbf{1 9 9 9}\end{array}$ & $\begin{array}{c}\text { Germany } \\
\mathbf{2 0 0 1 / 0 2}\end{array}$ & $\begin{array}{c}\text { United States* } \\
\mathbf{2 0 0 4 - 0 8}\end{array}$ \\
\hline $\begin{array}{l}\text { Activity: } \\
\text { Market work }\end{array}$ & 347 & 352 & 198 & 255 \\
Household production & 136 & 144 & 213 & 206 \\
Tertiary activities & 642 & 624 & 680 & 647 \\
Leisure & 315 & 320 & 349 & 332 \\
\hline
\end{tabular}

*For the U.S. 21 minutes of miscellaneous or unaccounted time was prorated across the four categories of activity. 
Table 2J. Changes in Minutes of Market Work Since 1976, Japan, 1986-2006*

\begin{tabular}{|c|c|c|c|c|c|c|c|c|c|c|c|c|}
\hline \multirow[b]{2}{*}{ Year: } & \multicolumn{3}{|c|}{ All Days } & \multicolumn{3}{|c|}{ Weekdays } & \multicolumn{3}{|c|}{ Saturdays } & \multicolumn{3}{|c|}{ Sundays } \\
\hline & All & Men & Women & All & Men & Women & All & Men & Women & All & Men & Women \\
\hline 1986 & $\begin{array}{c}1.05 \\
(2.06)\end{array}$ & $\begin{array}{c}0.11 \\
(2.55)\end{array}$ & $\begin{array}{c}2.19 \\
(2.38)\end{array}$ & $\begin{array}{c}7.06 \\
(1.76)\end{array}$ & $\begin{array}{c}6.85 \\
(1.89)\end{array}$ & $\begin{array}{c}8.10 \\
(2.60)\end{array}$ & $\begin{array}{c}4.32 \\
(2.72)\end{array}$ & $\begin{array}{c}3.22 \\
(2.95)\end{array}$ & $\begin{array}{c}3.48 \\
(3.63)\end{array}$ & $\begin{array}{l}-29.47 \\
(3.99)\end{array}$ & $\begin{array}{l}-34.46 \\
(4.76)\end{array}$ & $\begin{array}{l}-24.96 \\
(4.08)\end{array}$ \\
\hline 1991 & $\begin{array}{l}-2.72 \\
(2.09)\end{array}$ & $\begin{array}{r}-10.11 \\
(2.61)\end{array}$ & $\begin{array}{c}5.54 \\
(2.38)\end{array}$ & $\begin{array}{l}11.62 \\
(1.71)\end{array}$ & $\begin{array}{c}6.30 \\
(1.84)\end{array}$ & $\begin{array}{l}18.76 \\
(2.60)\end{array}$ & $\begin{array}{l}-32.83 \\
(2.78)\end{array}$ & $\begin{array}{l}-45.01 \\
(3.08)\end{array}$ & $\begin{array}{l}-22.14 \\
(3.63)\end{array}$ & $\begin{array}{r}-42.58 \\
(3.92)\end{array}$ & $\begin{array}{l}-54.19 \\
(4.65)\end{array}$ & $\begin{array}{l}-31.51 \\
(4.02)\end{array}$ \\
\hline 1996 & $\begin{array}{l}-17.11 \\
(2.19)\end{array}$ & $\begin{array}{l}-27.21 \\
(2.79)\end{array}$ & $\begin{array}{l}-5.58 \\
(2.46)\end{array}$ & $\begin{array}{c}1.27 \\
(1.84)\end{array}$ & $\begin{array}{l}-4.36 \\
(2.04)\end{array}$ & $\begin{array}{c}9.77 \\
(2.77)\end{array}$ & $\begin{array}{l}-71.1 \\
(2.77)\end{array}$ & $\begin{array}{l}-95.06 \\
(3.12)\end{array}$ & $\begin{array}{l}-49.54 \\
(3.62)\end{array}$ & $\begin{array}{l}-52.07 \\
(3.87)\end{array}$ & $\begin{array}{l}-68.15 \\
(4.58)\end{array}$ & $\begin{array}{l}-36.64 \\
(3.97)\end{array}$ \\
\hline 2001 & $\begin{array}{l}-27.26 \\
(2.19)\end{array}$ & $\begin{array}{l}-43.33 \\
(2.83)\end{array}$ & $\begin{array}{l}-9.37 \\
(2.51)\end{array}$ & $\begin{array}{l}-9.86 \\
(1.89)\end{array}$ & $\begin{array}{l}-22.20 \\
(2.20)\end{array}$ & $\begin{array}{c}5.85 \\
(2.83)\end{array}$ & $\begin{array}{l}-87.82 \\
(2.80)\end{array}$ & $\begin{array}{c}-118.74 \\
(3.22)\end{array}$ & $\begin{array}{r}-59.46 \\
(3.68)\end{array}$ & $\begin{array}{c}-51.54 \\
(3.90)\end{array}$ & $\begin{array}{l}-69.9 \\
(4.69)\end{array}$ & $\begin{array}{l}-33.73 \\
(4.05)\end{array}$ \\
\hline 2006 & $\begin{array}{l}-18.83 \\
(2.36)\end{array}$ & $\begin{array}{l}-35.74 \\
(3.06)\end{array}$ & $\begin{array}{c}0.78 \\
(2.64)\end{array}$ & $\begin{array}{c}2.34 \\
(2.03)\end{array}$ & $\begin{array}{l}-9.82 \\
(2.43)\end{array}$ & $\begin{array}{l}19.36 \\
(2.96)\end{array}$ & $\begin{array}{l}-92.46 \\
(2.96)\end{array}$ & $\begin{array}{c}-125.95 \\
(3.46)\end{array}$ & $\begin{array}{l}-61.72 \\
(3.77)\end{array}$ & $\begin{array}{l}-46.65 \\
(3.98)\end{array}$ & $\begin{array}{l}-66.6 \\
(4.76)\end{array}$ & $\begin{array}{l}-27.19 \\
(4.19)\end{array}$ \\
\hline $\mathrm{R}^{2}$ & 0.219 & 0.168 & 0.148 & 0.322 & 0.298 & 0.204 & 0.143 & 0.105 & 0.087 & 0.049 & 0.022 & 0.037 \\
\hline $\mathrm{N}=$ & 2449297 & 1152241 & 1297056 & 1047384 & 492348 & 555036 & 700020 & 329164 & 370856 & 701877 & 330723 & 371154 \\
\hline
\end{tabular}

*Each regression also includes indicators for educational attainment and a quadratic in age. The specifications for all adults also include an indicator for female. 
Table 2K. Changes in Minutes of Market Work Since 1999, Korea, 2004 and 2009*

\begin{tabular}{|c|c|c|c|c|c|c|c|c|c|c|c|c|}
\hline \multirow[b]{2}{*}{ Year: } & \multicolumn{3}{|c|}{ All Days } & \multicolumn{3}{|c|}{ Weekdays } & \multicolumn{3}{|c|}{ Saturdays } & \multicolumn{3}{|c|}{ Sundays } \\
\hline & All & Men & Women & All & Men & Women & All & Men & Women & All & Men & Women \\
\hline 2004 & $\begin{array}{r}-15.98 \\
(1.81)\end{array}$ & $\begin{array}{l}-24.53 \\
(2.64)\end{array}$ & $\begin{array}{l}-5.44 \\
(2.40)\end{array}$ & $\begin{array}{l}-4.34 \\
(2.20)\end{array}$ & $\begin{array}{r}-10.88 \\
(3.09)\end{array}$ & $\begin{array}{c}4.60 \\
(3.00)\end{array}$ & $\begin{array}{l}-42.96 \\
(3.67)\end{array}$ & $\begin{array}{l}-59.36 \\
(5.50)\end{array}$ & $\begin{array}{l}-25.54 \\
(4.73)\end{array}$ & $\begin{array}{l}-37.37 \\
(3.43)\end{array}$ & $\begin{array}{l}-48.00 \\
(5.47)\end{array}$ & $\begin{array}{l}-26.19 \\
(4.16)\end{array}$ \\
\hline 2009 & $\begin{array}{l}-18.29 \\
(2.10)\end{array}$ & $\begin{array}{l}-32.35 \\
(3.04)\end{array}$ & $\begin{array}{c}0.74 \\
(2.83)\end{array}$ & $\begin{array}{c}2.02 \\
(2.53)\end{array}$ & $\begin{array}{l}-7.71 \\
(3.51)\end{array}$ & $\begin{array}{l}17.75 \\
(3.53)\end{array}$ & $\begin{array}{c}-78.94 \\
(4.25)\end{array}$ & $\begin{array}{c}-110.10 \\
(6.42)\end{array}$ & $\begin{array}{c}-44.64 \\
(5.44)\end{array}$ & $\begin{array}{l}-46.59 \\
(3.89)\end{array}$ & $\begin{array}{c}-61.64 \\
(6.10)\end{array}$ & $\begin{array}{l}-29.75 \\
(4.80)\end{array}$ \\
\hline $\mathrm{R}^{2}$ & 0.166 & 0.103 & 0.144 & 0.231 & 0.169 & 0.192 & 0.144 & 0.102 & 0.106 & 0.062 & 0.045 & 0.057 \\
\hline $\mathrm{N}=$ & 172,080 & 80,325 & 91,755 & 103,840 & 48,389 & 55,451 & 34,427 & 16,115 & 18,312 & 33,813 & 15,821 & 17,992 \\
\hline
\end{tabular}

*Each regression also includes years of schooling, a quadratic in age, and an indicator of metropolitan location. The specifications for all adults also include an indicator for female. 
Table 3.Within-Estimates of Trends in Weekday-Weekend Differences in Minutes of Market Work, Japan, 1976-2006, Korea, 1999-2009*

a. Japan

\begin{tabular}{|c|c|c|c|c|c|c|}
\hline \multirow{2}{*}{$\begin{array}{l}\text { Interaction with: } \\
\text { Year: }\end{array}$} & Saturday & Sunday & Saturday & Sunday & Saturday & Sunday \\
\hline & \multicolumn{2}{|c|}{ All } & \multicolumn{2}{|c|}{ Male } & \multicolumn{2}{|c|}{ Female } \\
\hline 1986 & $\begin{array}{l}-15.39 \\
(2.40)\end{array}$ & $\begin{array}{l}-39.05 \\
(3.48)\end{array}$ & $\begin{array}{l}-22.07 \\
(3.90)\end{array}$ & $\begin{array}{l}-44.14 \\
(5.46)\end{array}$ & $\begin{array}{c}-6.7 \\
(2.81)\end{array}$ & $\begin{array}{l}-30.34 \\
(4.15)\end{array}$ \\
\hline 1991 & $\begin{array}{l}-54.77 \\
(2.55)\end{array}$ & $\begin{array}{l}-45.17 \\
(3.57)\end{array}$ & $\begin{array}{l}-68.72 \\
(4.20)\end{array}$ & $\begin{array}{l}-58.02 \\
(5.63)\end{array}$ & $\begin{array}{l}-41.51 \\
(2.95)\end{array}$ & $\begin{array}{l}-32.79 \\
(4.16)\end{array}$ \\
\hline 1996 & $\begin{array}{l}-67.93 \\
(2.74)\end{array}$ & $\begin{array}{l}-35.61 \\
(3.63)\end{array}$ & $\begin{array}{l}-92.72 \\
(4.52)\end{array}$ & $\begin{array}{l}-50.3 \\
(5.74)\end{array}$ & $\begin{array}{l}-45.74 \\
(3.15)\end{array}$ & $\begin{array}{l}-21.73 \\
(4.26)\end{array}$ \\
\hline 2001 & $\begin{array}{l}-70.46 \\
(3.18)\end{array}$ & $\begin{array}{l}-33.98 \\
(4.02)\end{array}$ & $\begin{array}{l}-96.87 \\
(5.20)\end{array}$ & $\begin{array}{l}-51.11 \\
(6.49)\end{array}$ & $\begin{array}{l}-46.00 \\
(3.64)\end{array}$ & $\begin{array}{l}-18.18 \\
(4.55)\end{array}$ \\
\hline 2006 & $\begin{array}{l}-90.56 \\
(3.45)\end{array}$ & $\begin{array}{l}-28.45 \\
(4.24)\end{array}$ & $\begin{array}{l}-120.09 \\
(5.60)\end{array}$ & $\begin{array}{l}-48.60 \\
(6.77)\end{array}$ & $\begin{array}{l}-63.56 \\
(4.02)\end{array}$ & $\begin{array}{l}-11.32 \\
(4.67)\end{array}$ \\
\hline $\mathrm{R}^{2}$ (within) & 0.295 & & 0.392 & & 0.207 & \\
\hline $\mathrm{N}=$ & 620,821 & & 292,027 & & 328,794 & \\
\hline
\end{tabular}

b. Korea

\begin{tabular}{|c|c|c|c|c|c|c|}
\hline \multirow{2}{*}{$\begin{array}{l}\text { Interaction with } \\
\text { Year: }\end{array}$} & Saturday & Sunday & Saturday & Sunday & Saturday & Sunday \\
\hline & \multicolumn{2}{|c|}{ All } & \multicolumn{2}{|c|}{ Male } & \multicolumn{2}{|c|}{ Female } \\
\hline 2004 & $\begin{array}{l}-31.55 \\
(4.15)\end{array}$ & $\begin{array}{l}-25.14 \\
(6.18)\end{array}$ & $\begin{array}{l}-40.74 \\
(6.60)\end{array}$ & $\begin{array}{l}-39.45 \\
(9.71)\end{array}$ & $\begin{array}{l}-22.72 \\
(5.04)\end{array}$ & $\begin{array}{l}-12.46 \\
(7.39)\end{array}$ \\
\hline 2009 & $\begin{array}{l}-83.52 \\
(5.58)\end{array}$ & $\begin{array}{l}-33.70 \\
(7.07)\end{array}$ & $\begin{array}{c}-115.40 \\
(9.01)\end{array}$ & $\begin{array}{l}-52.28 \\
(10.88)\end{array}$ & $\begin{array}{l}-52.70 \\
(6.43)\end{array}$ & $\begin{array}{l}-14.83 \\
(8.58)\end{array}$ \\
\hline $\mathrm{R}^{2}$ (within) & 0.292 & & 0.368 & & 0.221 & \\
\hline $\mathrm{N}=$ & 69,288 & & 32,184 & & 37,104 & \\
\hline
\end{tabular}


Table 4J. Changes in Minutes of H, T and L Since 1976, Japan, 1986-2006*

\begin{tabular}{lccccccccc}
\hline & & All Adults & \multicolumn{9}{c}{ Men } & & \multicolumn{3}{c}{ Women } \\
Year & $\mathrm{H}$ & $\mathrm{T}$ & $\mathrm{L}$ & $\mathrm{H}$ & $\mathrm{T}$ & $\mathrm{L}$ & $\mathrm{H}$ & $\mathrm{T}$ & $\mathrm{L}$ \\
\hline \multirow{2}{*}{1986} & 2.48 & -23.36 & 19.83 & 5.31 & -18.31 & 21.65 & -0.92 & -19.88 & 18.61 \\
& $(0.84)$ & $(0.79)$ & $(1.44)$ & $(0.37)$ & $(1.48)$ & $(2.00)$ & $(1.55)$ & $(0.93)$ & $(1.40)$ \\
& & & & & & & & & \\
1991 & 0.69 & -27.86 & 29.89 & 9.76 & -19.85 & 32.58 & -9.48 & -23.79 & 27.73 \\
& $(0.86)$ & $(0.81)$ & $(1.46)$ & $(0.41)$ & $(1.48)$ & $(2.02)$ & $(1.54)$ & $(0.95)$ & $(1.42)$ \\
& & & & & & & & & \\
1996 & -0.51 & -19.00 & 36.62 & 12.19 & -9.98 & 39.83 & -14.68 & -13.67 & 33.94 \\
& $(0.88)$ & $(0.84)$ & $(1.54)$ & $(0.42)$ & $(1.51)$ & $(2.15)$ & $(1.59)$ & $(0.97)$ & $(1.50)$ \\
& & & & & & & & & \\
2001 & 2.15 & -21.71 & 46.82 & 18.99 & -14.02 & 51.63 & -16.62 & -16.61 & 42.6 \\
& $(0.93)$ & $(0.87)$ & $(1.55)$ & $(0.48)$ & $(1.55)$ & $(2.17)$ & $(1.66)$ & $(1.04)$ & $(1.52)$ \\
& & & & & & & & & \\
2006 & 4.30 & -24.91 & 39.44 & 24.30 & -15.75 & 41.34 & -18.11 & -20.44 & 37.78 \\
& $(1.01)$ & $(0.93)$ & $(1.64)$ & $(0.60)$ & $(1.62)$ & $(2.32)$ & $(1.78)$ & $(1.12)$ & $(1.64)$ \\
& & & & & & & & & \\
\hline $\mathrm{R}^{2}$ & 0.351 & 0.131 & 0.089 & 0.023 & 0.127 & 0.076 & 0.150 & 0.134 & 0.090 \\
\hline
\end{tabular}

*Sample sizes are the same as in Table 2J. The regressions include the same controls 
Table 4K. Changes in Minutes of H, T and L Since 1999, Korea, 2004 and 2009

\begin{tabular}{lcccccccccc}
\hline & \multicolumn{3}{c}{ All Adults } & \multicolumn{3}{c}{ Men } & \multicolumn{3}{c}{ Women } \\
& $\mathrm{H}$ & $\mathrm{T}$ & $\mathrm{L}$ & $\mathrm{H}$ & $\mathrm{T}$ & $\mathrm{L}$ & $\mathrm{H}$ & $\mathrm{T}$ & $\mathrm{L}$ \\
\hline \multirow{4}{*}{ Year 2004 } & & & & & & & & & & \\
& -13.22 & 20.99 & 8.21 & -4.16 & 21.48 & 8.21 & -24.04 & 20.96 & 7.21 \\
& $(0.93)$ & $(0.76)$ & $(1.38)$ & $(0.71)$ & $(1.12)$ & $(1.38)$ & $(1.61)$ & $(1.04)$ & $(2.17)$ \\
Year 2009 & -12.24 & 43.93 & -13.40 & 1.41 & 43.81 & -13.40 & -29.95 & 44.46 & -12.87 \\
& $(1.08)$ & $(0.88)$ & $(1.58)$ & $(0.87)$ & $(1.25)$ & $(1.58)$ & $(1.90)$ & $(1.23)$ & $(2.44)$ \\
& & & & & & & & & \\
\hline $\mathrm{R}^{2}$ & 0.340 & 0.065 & 0.083 & 0.014 & 0.060 & 0.083 & 0.156 & 0.074 & 0.076 \\
\hline
\end{tabular}

*Samples sizes are the same as in Table $2 \mathrm{~K}$. The regressions include the same controls as in that table. 
APPENDIX. Classification of Sub-aggregates into $M, H, T$ and $L$

\begin{tabular}{|c|c|c|}
\hline & Japan* & Korea** \\
\hline $\begin{array}{l}\text { Market Work } \\
\text { (M) }\end{array}$ & $\begin{array}{l}\text { Work } \\
\text { Schoolwork } \\
\text { Commuting to/from school or work } \\
\text { Studying and Researching }\end{array}$ & $\begin{array}{l}\text { Working and Work-Related } \\
\text { Activities } \\
\text { Educational Activities } \\
\text { Non-school Educational Activities }\end{array}$ \\
\hline $\begin{array}{l}\text { Household Production } \\
\text { (H) }\end{array}$ & $\begin{array}{l}\text { Housework } \\
\text { Child Care } \\
\text { Child care } \\
\text { Shopping }\end{array}$ & $\begin{array}{l}\text { Household Services } \\
\text { Caring for Household Members }\end{array}$ \\
\hline $\begin{array}{l}\text { Tertiary Activities } \\
\text { (T) }\end{array}$ & $\begin{array}{l}\text { Sleep } \\
\text { Personal Care } \\
\text { Meals } \\
\text { Medical Examination or Treatment }\end{array}$ & Personal Care (includes Sleep) \\
\hline $\begin{array}{l}\text { Leisure } \\
\text { (L) }\end{array}$ & $\begin{array}{l}\text { TV, Radio, Reading } \\
\text { Rest and Relaxation } \\
\text { Hobbies and Amusements } \\
\text { Sports } \\
\text { Volunteer and Social Activities } \\
\text { Social Life }\end{array}$ & $\begin{array}{l}\text { Volunteer Activities } \\
\text { Socializing and Leisure }\end{array}$ \\
\hline Prorated & $\begin{array}{l}\text { Travel Other than Commuting } \\
\text { Caring and Nursing } \\
\text { Other Activities }\end{array}$ & Other Activities \\
\hline & $\begin{array}{l}\text { *Schoolwork was first included in 1996, } \\
\text { Caring and Nursing from 1991. Non- } \\
\text { commuting travel is prorated across H, } \\
\mathrm{L} \text { and medical treatment. The rest is } \\
\text { prorated across all aggregates. }\end{array}$ & $\begin{array}{l}\text { **Travel for each activity is added to } \\
\text { the appropriate aggregate. }\end{array}$ \\
\hline
\end{tabular}

